\title{
Effects of Thyroid Dysfunction on Lipid Profile
}

\author{
C.V. Rizos, M.S. Elisaf and E.N. Liberopoulos*
}

Department of Internal Medicine, School of Medicine, University of Ioannina, Ioannina, Greece

\begin{abstract}
Thyroid dysfunction has a great impact on lipids as well as a number of other cardiovascular risk factors. Hypothyroidism is relatively common and is associated with an unfavorable effect on lipids. Substitution therapy is beneficial for patients with overt hypothyroidism, improving lipid profile. However, whether subclinical hypothyroidism should be treated or not is a matter of debate. On the other hand, hyperthyroidism can be associated with acquired hypocholesterolemia or unexplained improvement of lipid profile. Overall, thyroid dysfunction should be taken into account when evaluating and treating dyslipidemic patients.
\end{abstract}

Keywords: Cardiovascular disease, dyslipidemia, hypothyroidism, hyperthyroidism, lipoprotein (a), thyroid autoimmunity, thyroid dysfunction, thyroxine treatment.

\section{INTRODUCTION}

Thyroid function regulates a wide array of metabolic parameters. Thyroid function significantly affects lipoprotein metabolism as well as some cardiovascular disease (CVD) risk factors, thus influencing overall CDV risk [1-3]. Indeed, even within the normal range of thyroid-stimulating hormone (TSH) values, a linear increase in total cholesterol (TC), low-density lipoprotein cholesterol (LDL-C) and triglycerides (TGs) and a linear decrease in high-density lipoprotein cholesterol (HDL-C) levels has been observed with increasing TSH [4].

\section{MECHANISMS (FIG. 1)}

Thyroid hormones induce the 3-hydroxy-3-methylglutarylcoenzyme A (HMG-CoA) reductase, which is the first step in cholesterol biosynthesis. Moreover, triiodothyronine $\left(\mathrm{T}_{3}\right)$ upregulates LDL receptors by controlling the LDL receptor gene activation. This $\mathrm{T}_{3}$-mediated gene activation is done by the direct binding of $\mathrm{T}_{3}$ to specific thyroid hormone responsive elements (TREs) [5]. Furthermore, $\mathrm{T}_{3}$ controls the sterol regulatory element-binding protein-2 (SREBP-2), which in turn regulates LDL receptor's gene expression [6]. $\mathrm{T}_{3}$ has also been associated with protecting LDL from oxidation [7].

Thyroid hormones can influence HDL metabolism by increasing cholesteryl ester transfer protein (CETP) activity, which exchanges cholesteryl esters from $\mathrm{HDL}_{2}$ to the very low density lipoproteins (VLDL) and TGs to the opposite direction [8]. In addition, thyroid hormones stimulate the lipoprotein lipase (LPL), which catabolizes the TG-rich lipoproteins, and the hepatic lipase (HL), which hydrolyzes $\mathrm{HDL}_{2}$ to $\mathrm{HDL}_{3}$ and contributes to the conversion of intermediate-density lipoproteins (IDL) to LDL and in turn LDL to

*Address correspondence to this author at the Department of Internal Medicine, Medical School, University of Ioannina, Ioannina 45110, Greece; Tel: +30-26510-07502; Fax: +30-26510-07016;

E-mail:vaglimp@yahooo.com small dense LDL (sdLDL) $[9,10]$. Another effect of $\mathrm{T}_{3}$ is the up-regulation of apolipoprotein AV (ApoAV), which plays a major role in TG regulation [11]. Indeed, increased levels of ApoAV have been associated with decreased levels of TGs [12]. Proposed mechanisms for this effect include the decrease of hepatic VLDL-TG production and the increase of plasma LPL levels and activity, resulting in increase of lipoprotein remnant generation due to enhanced LPL-mediated lipolysis of VLDL-TG [12]. Moreover, a greater clearance of lipoprotein core remnants, caused by increased hepatic uptake due to an enhanced affinity for the LDL receptor, has also been ascribed to ApoAV [12].

Beyond their effect on lipid profile thyroid hormones can equally affect a number of other metabolic parameters related to CVD risk. Indeed, thyroid function can influence adipocyte metabolism and the production of adipokines [1315]. Hyperthyroidism has been associated with increased levels of adiponectin, whereas hypothyroidism is not associated with significant changes in adiponectin [13, 15]. Insulin resistance is also correlated with thyroid function [16-19]. TSH is positively associated with fasting and postprandial insulin concentration and negatively with insulin sensitivity [17]. Moreover, low normal FT4 levels are significantly associated with increased insulin resistance [19]. Oxidative stress is also affected by thyroid function with studies however showing controversial outcomes [7, 20]. Furthermore, endothelial [17] and cardiac function as well as atherosclerosis [21] have been positively associated with thyroid hormone levels. A positive association between TSH and body mass index (BMI) or waist circumference has also been described $[22,23]$. A large population trial using data from the fourth and fifth Tromso study showed that this association between TSH and BMI was only significant in non smokers [24].

The effects of thyroid dysfunction on lipid parameters and CVD risk factors as well as the influence of substitution therapy are discussed below. 

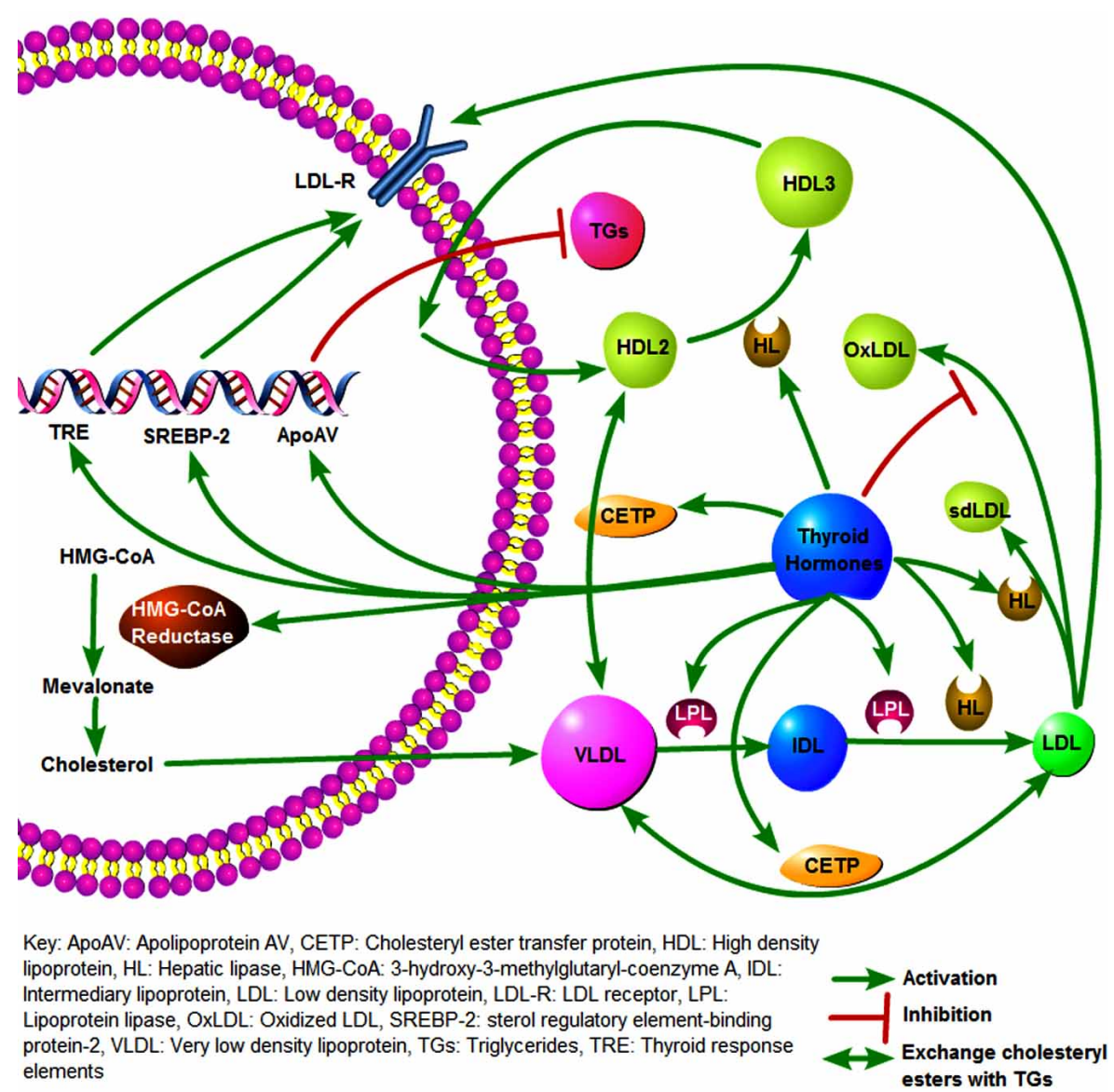

Fig. (1). Effects of thyroid hormones on lipid metabolism.

\section{HYPOTHYROIDISM}

Hypothyroidism is a common metabolic disorder in the general population. Indeed, data from the third National Health and Nutrition Examination Survey (NHANES III) showed a $4.6 \%$ prevalence of hypothyroidism in the general population, while $9.5 \%$ of the Colorado prevalence study participants had elevated levels of TSH [3]. Thyroid failure is more common in women and its prevalence rises with age. Hypothyroid patients have increased levels of TC and LDLC [3]. Indeed, hypothyroidism is a common cause of secondary dyslipidemia $[25,26]$.

\section{i. Overt Hypothyroidism}

\section{a. Lipid Profile}

Although decreased thyroid function is accompanied by reduced activity of HMG-CoA reductase, TC and LDL-C levels are increased in patients with overt hypothyroidism [27-31]. This is due to the decreased LDL-receptors' activity, resulting in decreased catabolism of LDL and IDL [3234]. Moreover, a decrease in LPL activity is found in overt hypothyroidism, decreasing the clearance of TG-rich lipoproteins [35]. Therefore, overt hypothyroid patients may also present with elevated TG levels associated with increased levels of VLDL and occasionally fasting chylomicronemia [29-31, 34]. The VLDL and IDL particles in hypothyroidism are rich in cholesterol and apolipoprotein $\mathrm{E}$, thus resembling $\beta$-VLDL particles of type III hyperlipoproteinemia. Therefore, the full-blown clinical syndrome of the type III hyper- lipoproteinemia may develop in patients homozygous for the apolipoprotein E2 allele if they become hypothyroid.

Hypothyroid patients may also exhibit elevated levels of HDL-C [27] mainly due to increased concentration of $\mathrm{HDL}_{2}$ particles. Indeed, due to a reduction of HL activity a decrease in $\mathrm{HDL}_{2}$ catabolism is observed. [36]. Moreover, decreased activity of the CETP results in reduced transfer of cholesteryl esters from HDL to VLDL, thus increasing HDLC levels [37]. Hypothyroid patients have increased lipoprotein (a) $[\mathrm{Lp}(\mathrm{a})]$ levels $[38,39]$, which are associated with increased CVD risk [39, 40].

Beyond the levels of LDL-C, the qualitative composition of LDL-C plays an important role in CVD development. Indeed, increased sdLDL concentration increases the risk for CVD [41]. Trials evaluating the effects of overt hypothyroidism on LDL subfractions have shown conflicting results. A study in newly-diagnosed hypothyroid patients $(n=60)$ showed that hypothyroidism was associated with higher prevalence of sdLDL [28]. On the other hand, there have been studies showing no significant differences between overt hypothyroid patients and healthy controls regarding sdLDL levels [42, 43]. Another study evaluated the effects of short-term overt hypothyroidism on LDL subfractions [27]. Thyroidectomized patients $(n=28)$ were withdrawn from substitution therapy for 2-3 weeks in preparation for radioactive iodine ablation. Patients exhibited an increase in LDL-C that was found to be primarily due to increases in the large LDL particles, while sdLDL did not significantly change [27]. 


\section{b. CVD Risk}

The above abnormalities of lipid metabolism associated with overt hypothyroidism predispose to the development of atherosclerotic coronary artery disease (CAD) [44, 45]. Moreover, hypothyroidism can adversely affect other CVD risk factors, further contributing to increasing CAD risk. Decreased thyroid function not only increases the number of LDL particles, but also promotes LDL oxidability [46]. Furthermore, hypothyroidism increases plasma homocysteine levels [47-50], which can be attributed to the hypothyroidism-induced decline of kidney function [51] as well as impaired methylenetetrahydrofolate reductase activity [52]. In addition, thyroid failure is strongly associated with arterial hypertension (especially diastolic) [53-55] via sympathetic and adrenal activation [53], and increased vascular stiffness $[54,56,57]$. Subjects with overt hypothyroidism also exhibit impaired endothelial function [58], increased uric acid [28] and phosphate levels [29], all of which are associated with increased CVD risk [59, 60].

In addition, an increase in carotid intima media thickness (CIMT) has been observed in hypothyroid patients [61]. Hypothyroidism is also accompanied by increased prevalence of metabolic syndrome [62] and waist-to-hip ratio [63]. Insulin resistance is increased in thyroid failure [64], while a decrease in GLUT4 glucose transporters (leading to a reduction of glucose uptake and promoting insulin resistance [65]) is observed [64]. Moreover, there are indications of increased high-sensitivity C-reactive protein (hsCRP) levels in hypothyroidism $[28,49]$ although there are studies which do not support this notion [31,50].

\section{c. Substitution Therapy}

Administration of substitution therapy with L-thyroxine significantly improves lipid metabolism abnormalities. A period of 4-6 weeks of thyroxin replacement therapy is usually needed to correct dyslipidemia in overt hypothyroidism. In general, changes in serum lipoproteins in hypothyroid patients are correlated with changes in free $\mathrm{T}_{4}\left(\mathrm{FT}_{4}\right)$ [66]. A study in newly-diagnosed hypothyroid patients $(\mathrm{n}=60)$ showed a decrease in serum TC and LDL-C levels after thyroxine treatment [28]. However, when the effects of substitution therapy on qualitative lipid profile were assessed no change in LDL particle size was seen [28]. A more dramatic reduction of TC levels has been observed in hypothyroid patients with higher baseline TSH levels [67].

Serum HDL-C levels tend to decrease with thyroid replacement, but this is a less consistent finding [68]. Serum $\mathrm{Lp}$ (a) levels also tend to decrease with restoration of euthyroidism [25, 39]. Moreover, a decrease in CIMT has been observed after thyroxine treatment in hypothyroid patients [61].

The presence of overt hypothyroidism in patients with dyslipidemia is not rare. We found that $2.8 \%$ of the patients who visited our outpatient lipid clinic with dyslipidemia had elevated levels of TSH and reduced levels of $\mathrm{FT}_{4}$ [25]. After restoration of euthyroidism with levothyroxine therapy, a significant decrease of serum levels of TC and LDL-C, apolipoprotein B (ApoB) and Lp(a) was observed, while levels of HDL-C, TGs and apolipoprotein AI (ApoAI) were not significantly changed [25]. Superimposed dyslipidemia should be taken into account in cases of failure of substitution ther- apy to normalize the lipid profile despite the restoration of euthyroidism [1].

Hypothyroidism is one of the most common causes of secondary dyslipidemia. Therefore, before starting hypolipidemic therapy, the evaluation of thyroid function is needed. Thyroid failure is associated with increased levels of creatinine kinase (CK) [69]. Statin therapy may substantially increase levels of CK. A study examined the effects of accidentally starting statin therapy in patients with undiagnosed hypothyroidism $(n=9)$ [70]. These patients had significantly higher CK levels (1095 U/L) compared with untreated hypothyroid patients matched for free $T_{4}$ levels $(n=18 ; C K=395$; $\mathrm{p}<0.05)$ [70]. Therefore, it is imperative to firstly correct thyroid dysfunction with thyroxine substitution therapy and then treat the underlying dyslipidemia with statins.

\section{ii. Subclinical Hypothyroidism}

Subclinical hypothyroidism (SH), defined as the clinical status of elevated serum TSH levels with normal levels of $\mathrm{FT}_{4}$ and $\mathrm{FT}_{3}$, is a far more common disorder than overt hypothyroidism. The prevalence of SH in the general population is estimated at $4.3 \%-9 \%[3,71]$. SH has a higher prevalence among women and older populations [3, 72-74]. Moreover, SH may progress to overt hypothyroidism. The rate of progression is higher with the concomitant presence of thyroperoxidase antibodies (TPO-Ab) or higher levels of TSH [75].

\section{a. Lipid Profile}

SH is associated with increased levels of TC and LDL-C [63, 72, 74, 76-80]. In addition, some studies have shown that $\mathrm{SH}$ dyslipidemia may also be accompanied by increased TGs [81, 82] and decreased HDL-C levels [83]. Moreover, subjects with high normal TSH levels (2-4 mIU/L), but with positive antithyroid antibodies may also exhibit elevated cholesterol levels [84]. In a cross-sectional study we evaluated serum lipid parameters of SH patients $(n=66)$ and ageand sex- matched euthyroid controls $(n=75)$ [85]. Patients with SH had significantly higher levels of TC, LDL-C and ApoB, whereas levels of TGs, HDL-C and ApoAI did not differ significantly compared with euthyroid controls [85]. Similarly, results from the fifth Tromso Study showed increased levels of LDL-C in SH patients ( $n=84)$ [86].

Most studies have shown increased $\mathrm{Lp}(\mathrm{a})$ levels related to $\mathrm{SH}[85,87,88]$. An interesting study evaluated serum $\mathrm{Lp}$ (a) levels along with corresponding apolipoprotein(a) [apo(a)] phenotypes, which are known to influence $L p(a)$ levels, in SH patients [89]. SH patients had higher Lp(a) levels compared with controls $(\mathrm{p}=0.003)$. Of note, no significant difference in the frequencies of apo(a) phenotypes were detected between patients with $\mathrm{SH}(\mathrm{n}=69)$ and controls $(\mathrm{n}=83)$.

Thyroid autoimmunity may also play an important role in the elevation of $\mathrm{Lp}(\mathrm{a})$ levels. It has been reported that euthyroid males and postmenopausal females with evidence of thyroid autoimmunity (increased titers of TPO-Ab and/or thyroglobulin autoantibodies) have increased Lp(a) levels [90]. On the other hand, a study compared the levels of $\mathrm{Lp}$ (a) of 22 euthyroid subjects ( 9 male and 13 postmenopausal female) with thyroid autoimmunity with those of 64 age- and sex-matched controls without thyroid autoimmunity [91]. There were no significant differences in the values of lipid 
parameters, including $\operatorname{Lp}(\mathrm{a})$, between the two groups even when apo(a) phenotypes were taken into account [91]. Moreover, no significant difference in the $\mathrm{Lp}(\mathrm{a})$ levels was found in euthyroid patients with chronic renal failure regardless of the presence of thyroid autoimmunity, the apo(a) phenotype, the stage of renal failure and the mode of dialysis in end stage patients [92]. Furthermore, the presence of thyroid autoimmunity has not been shown to influence serum lipid parameters in $\mathrm{SH}$ subjects [85].

There is some controversy regarding the presence or the severity of SH-induced dyslipidemia. Indeed, there have been studies indicating no significant difference in lipid profile between SH patients and controls [29-31, 93]. Data from the NHANES III revealed increased levels of TC in SH patients $(n=215)$ vs controls $(n=8013)$ [94]. However, when adjusted for age, race, sex and the use of lipid-lowering drugs no difference was observed between $\mathrm{SH}$ and controls regarding lipid profile. Moreover, there have been studies questioning the effects of thyroid hormones on Lp(a) levels. Various studies have shown no difference between $\mathrm{SH}$ and control subjects regarding $\mathrm{Lp}$ (a) levels [39, 82, 95, 96]. Lee et. al compared patients covering the whole spectrum of thyroid function and found no differences in $\mathrm{Lp}$ (a) between groups [31]. Moreover, no correlation was found between $\mathrm{Lp}$ (a) levels and TSH or $\mathrm{FT}_{4}$ [31]. On the contrary, in a study with $\mathrm{SH}$ patients $(\mathrm{n}=38)$ a significant negative correlation $(\mathrm{r}=-0.31 ; \mathrm{p}=0.03)$ was observed between $\mathrm{FT}_{3}$ levels and $\mathrm{Lp}$ (a) [82].

An association between lipids, thyroid function and insulin resistance has been observed [18]. The analysis of a subgroup from the Fremantle Diabetes Study (FDS) showed that the association of TSH levels and lipid profile is significant mainly in the presence of insulin resistance. Similar results were shown in a study in euthyroid subjects [97].

An interesting aspect of the potential SH-mediated dyslipidemia is the qualitative effects of thyroid hormones on lipids. A study compared SH women $(n=21)$ with female controls $(n=11)$ [93]. No difference was found regarding lipid profile between the 2 groups. However, decreased ratio of cholesterol/triglycerides in LDL $(\mathrm{p}<0.02)$ in SH subjects vs controls indicated the presence of more TG-enriched LDL particles in those subjects. On the other hand, a study in $\mathrm{SH}$ patients $(n=57)$ did not reveal any differences in LDL particle size compared with controls [42].

\section{b. CVD Risk}

Beyond lipids, SH can have a deleterious effect on several other CVD risk factors. SH has been associated with a hypercoagulable state [77, 83]. Furthermore, SH impairs ventricular function as well as cardiovascular and respiratory adaptation to effort and decreases heart rate variability [98, 99]. Moreover, SH decreases flow-mediated vasodilation and nitric oxide (NO) availability, which are markers of endothelial function [98, 99]. An increase in CIMT has also been described in $\mathrm{SH}$ patients compared with controls [78, 79]. However, a study in SH patients $(n=21)$ did not confirm such an increase in CIMT compared with euthyroid subjects [100]. Although SH patients with TPO-Ab had higher CIMT values compared with $\mathrm{SH}$ patients without $\mathrm{TPO}-\mathrm{Ab}$ this difference was not significant [100].
A study showed a higher incidence of multi-vessel disease in angina patients $(n=344)$ with high TSH values although TSH was not established as a predictor for coronary artery stenosis [101]. On the other hand, a study in hypothyroid patients $(n=794,90 \%$ of whom had $\mathrm{SH})$ did not reveal any differences regarding carotid atherosclerosis (carotid plaques prevalence, severity and CIMT) compared with euthyroid subjects $(n=1588)$ after adjusting for various CVD risk factors [102]. SH has also been associated with other CVD risk factors, such as increase in insulin resistance [64, 103].

SH subjects have been described to have higher plasma lipoprotein-associated phospholipase $\mathrm{A}_{2}\left(\mathrm{Lp}-\mathrm{PLA}_{2}\right)$ (which is a known CVD marker [104]) and lower HDL Lp-PLA 2 (which is associated with the antiatherogenic effects of HDL [105]) activity [81]. Moreover, a negative association between free thyroxine and hsCRP levels has been described [106]. Indeed, increased hsCRP levels have been found in SH patients [49]. A study demonstrated a linear correlation between blood pressure and TSH even within the normal reference ranges [107]. However, a large cross-sectional study in SH patients $(\mathrm{n}=806)$ did not find any association between $\mathrm{SH}$ and increased blood pressure [108]. In addition, smoking may deteriorate the lipid profile in women with $\mathrm{SH}$ and aggravate the degree of thyroid failure, thus contributing to the development of atherosclerosis [109].

As described above, $\mathrm{SH}$ is positively correlated with increased prevalence of some CVD risk factors. However, it is imperative to investigate the available data on the incidence of CVD morbidity and mortality in SH subjects. A metaanalysis of 14 trials found an increase in risk of CVD (odds ratio [OR] $1.65 ; 95 \%$ CI 1.28-2.12) in subjects with $\mathrm{SH}$ [110]. An interesting study evaluated the association of $\mathrm{SH}$ with the incidence of congestive heart failure (CHF), CAD, stroke, peripheral artery disease and CVD or total mortality [111]. This was a prospective analysis in a longitudinal cohort study of older adults (aged 70-79 years old) from the Health, Aging, and Body Composition (HEALTH ABC) study. SH subjects $(n=338)$ were subdivided in groups according to their TSH levels. Patients with TSH levels $\geq 7$ $\mathrm{mIU} / \mathrm{L}$ had a greater risk for CHF $(\mathrm{p}=0.006)$. SH was not associated with increased prevalence of stroke, peripheral artery disease and CVD mortality. However, SH subjects with $\mathrm{TSH} \geq 10 \mathrm{mIU} / \mathrm{L}$ had a higher risk for myocardial infarction (MI) (hazard ratio [HR] 4.73 95\% CI 1.01-22.13) and total mortality (HR $3.1395 \%$ CI 1.11-8.79). Similarly, a recent meta-analysis found a $41 \%$ increase in all cause mortality in SH patients compared with euthyroid subjects [112]. Another study in SH patients $(n=257)$ found a positive correlation between $\mathrm{SH}, \mathrm{CAD}$ and total mortality which however was limited only to men (OR 4; 95\% CI 1.4 - 11.5) [113].

Of interest are the results from studies evaluating the effects of SH in elderly populations. The Rotterdam study found an association between $\mathrm{SH}$ and aortic atherosclerosis (OR 1.7; 95\% CI 1.1 - 2.6) and MI (OR 2.3; 95\% CI 1.3 - 4) in elderly SH women [114]. Moreover, the presence of TPO$\mathrm{Ab}$ increased the risk for both aortic atherosclerosis (OR 1.9; 95\% CI 1.1 - 3.6) and MI (OR 3.1; 95\% CI 1.5 - 6.3). However, the presence of TPO-Ab in total study population was not associated with a history of MI. On the other hand, the Cardiovascular Health Study (CHS) did not find any link be- 
tween SH and CVD morbidity and mortality in an elderly SH population, although an increased incidence of atrial fibrillation was observed [115]. Moreover, a study evaluated the association of thyrotropin with disability and survival in the Leiden 85-Plus Study elderly population [116]. The results indicated that abnormally high levels of thyrotropin not only did not affect cognitive and mental status but rather prolonged life span [116].

\section{c. Substitution Therapy}

A beneficial effect of substitution therapy on lipid parameters and especially $\mathrm{TC}$ and LDL-C in some patients with $\mathrm{SH}$ has been shown [30, 72, 88, 117-120]. In a metaanalysis, the mean decrease of serum TC and LDL-C levels after thyroxine substitution was $-7.9 \mathrm{mg} / \mathrm{dL}$ and $-10 \mathrm{mg} / \mathrm{dL}$, respectively [72]. The reduction was larger in individuals with higher pretreatment cholesterol levels and in hypothyroid individuals taking suboptimal $\mathrm{T}_{4}$ doses [72]. The fifth Tromso study [86] evaluated the effects of thyroxine $(n=32)$ compared with placebo $(n=32)$ in $\mathrm{SH}$ patients. Thyroxine was administered with a goal of TSH levels of 0.5-1.5 $\mathrm{mIU} / \mathrm{L}$. The effect of thyroxine therapy on lipid profile was a significant decrease of only ApoB levels $(\mathrm{p}<0.01)$. However, when examining the subgroup of patients $(n=23)$ with posttreatment TSH levels $0.2-2 \mathrm{mIU} / \mathrm{L}$ a significant decrease in TC $(\mathrm{p}<0.05)$ and LDL-C $(\mathrm{p}<0.01)$ was also seen. Moreover, thyroxine substitution therapy may have additional advantageous effects to offer beyond the improvement of lipid profile. Indeed, a reduction in CIMT [78, 79] and improvement of endothelial function [99] has been described in $\mathrm{SH}$ patients after thyroxine replacement. In addition, thyroxine therapy increased HDL-associated Lp-PLA 2 activity in $\mathrm{SH}$ subjects [81].

These findings, however, are not consistently corroborated by other studies. Indeed, some studies showed no significant effect of thyroxine therapy on lipid profile in $\mathrm{SH}$ patients $[78,93,121,122]$. Interesting were the results of a study evaluating the effects of thyroxine in $\mathrm{SH}$ subjects $(n=66)$ [85]. Lipid profile was not significantly altered with the exception of a decrease in HDL-C levels $(\mathrm{p}<0.05)$. However, in the subgroup of patients with $\mathrm{TC} \geq 240 \mathrm{mg} / \mathrm{dL}$ $(\mathrm{n}=14)$ or $\mathrm{TSH} \geq 10 \mathrm{mIU} / \mathrm{L}(\mathrm{n}=18)$ a decrease in TC $(\mathrm{p}<0.05)$ and LDL-C $(\mathrm{p}<0.01)$ was also observed. A recent metaanalysis showed no benefits in survival or CVD mortality after substitution therapy in SH patients [123]. Moreover, thyroxine replacement did not improve quality of life, although a beneficial effect was seen in some lipid parameters and left ventricular function [123].

The beneficial effects of thyroxine substitution therapy on Lp(a) levels in SH subjects are also debated. Several studies have shown no impact of thyroxine therapy on Lp(a) levels in SH patients [39, 40, 85, 88]. However, other studies showed a significant decrease of $\mathrm{Lp}$ (a) levels after thyroxine treatment [89, 118]. A study with $17 \mathrm{SH}$ women demonstrated a reduction of $\mathrm{Lp}(\mathrm{a})$ by $23.5 \%(\mathrm{p}=0.0005)$ compared with baseline after substitution therapy [118]. Milionis et al. demonstrated that thyroxine treatment was effective in reducing Lp(a) levels in SH subjects $(p=0.008)$ [89]. Of interest was that this reduction of $L p(a)$ levels achieved significance only in the low molecular weight apo(a) isoforms subgroup of patients [89].

\section{d. Should we Treat SH Patients?}

Although it is clear that thyroid replacement therapy has beneficial effects on serum lipid profile and CVD risk in overt hypothyroid patients, no clear consensus has been established regarding the treatment of SH subjects [124, 125]. This is due to the fact that there are no data from large trials on whether and to what degree does $\mathrm{SH}$ affect lipid profile. Moreover, data are lacking on the overall effect of substitution therapy on morbidity and mortality in SH patients. A significant query is whether all $\mathrm{SH}$ patients would benefit from thyroxine replacement therapy or such therapy should be reserved for selected subgroups. Furthermore, there has not been enough evidence regarding the long-term effects of thyroid replacement in $\mathrm{SH}$ patients and therefore no clear recommendations can be made [126].

It seems that thyroid substitution, if used, would be most beneficial in patients with prominent thyroid dysfunction (TSH levels >10 mIU/L), higher initial cholesterol levels, smokers and subjects with positive TPO-Ab. Moreover, levothyroxine treatment may play an important role in other aspects of CVD risk beyond lipids. Of note, the potential adverse effects of levothyroxine therapy should also be taken into account. Thyroid substitution may decrease HDL-C concentration, undermining the beneficial effect of TC and LDL-C reduction in these patients. Furthermore, when treating people with angina pectoris or heart disease, one should be very cautious because thyroxin therapy may exacerbate angina or promote cardiac arrhythmia.

Overall, measurement of serum TSH levels should be included in the screening of patients with dyslipidemia [1, 127, 128]. Hypercholesterolemic patients with $\mathrm{SH}$ may be treated with thyroxin substitution therapy, since the restoration of euthyroidism can effectively improve lipid levels, relieve certain symptoms, and may also prevent progression to overt hypothyroidism [129].

\section{OVERT AND SUBCLINICAL HYPERTHYROIDISM}

The incidence of hyperthyroidism is lower (2.2\%) [3] compared with hypothyroidism in the general population. Similarly, a decreased prevalence of hyperthyroidism is evident in hyperlipidemic patients, since only 3 out of the 248 patients in our study had thyrotoxicosis [25].

Despite the increased activity of the HMG-CoA reductase, levels of TC, LDL-C, ApoB and Lp(a) tend to decrease in patients with clinical or subclinical hyperthyroidism. This is due to increased LDL receptor gene expression resulting in enhanced LDL receptor-mediated catabolism of LDL particles [130, 131]. Moreover, no difference in LDL subfraction distribution has been observed between subclinical or overt hyperthyroid versus euthyroid subjects [42]. Furthermore, hyperthyroidism results in enhanced LDL oxidability, which is related to $\mathrm{FT}_{4}$ levels [46].

A decrease in HDL-C levels is also observed in hyperthyroidism, due to increased CETP-mediated transfer of cholesteryl esters from HDL to VLDL and increased HL-mediated catabolism of $\mathrm{HDL}_{2}[130,131]$. Triglyceride levels remain unchanged. On the other hand, no changes in blood pressure [108], Lp(a) [31] or hsCRP levels [31] have been described in hyperthyroid patients. However, an increase in factor $\mathrm{X}$ 
activity has been observed in subclinical hyperthyroidism patients, indicating a hypercoagulable state [77]. Therapy of clinical hyperthyroidism results in restoration of those alterations of lipid metabolism [130, 131], while the effects of treatment of subclinical hyperthyroidism subjects are not yet clear [132].

Iatrogenic hyperthyroidism has been associated with MI in subjects without coronary stenosis $[133,134]$. Similarly, there have been case reports associating subclinical hyperthyroidism with MI [135], recurrent pulmonary embolism [136] and atrial fibrillation [135, 136].

Hyperthyroidism not only consists a significant cause of acquired hypobetalipoproteinemia, but it can also be the underlying cause of unexpected improvement of lipid profile in hyperlipidemic patients [137]. In the latter case, therapy of thyrotoxicosis restores the lipid parameters to the previously elevated levels [137].

\section{CONCLUSION}

Thyroid dysfunction can have an important effect on lipid profile [138]. Biochemical screening for thyroid dysfunction is critical in all dyslipidemic patients, as well as in all patients with unexpected improvement or worsening of their lipid profile. Underlying thyroid disorders should be recognized and treated in this setting.

There have been studies suggesting that screening for thyroid dysfunction is cost effective [139]. The American Thyroid Association recommends that adults be screened for thyroid dysfunction by measurement of the serum TSH concentration, beginning at age 35 years and every 5 years thereafter [140]. On the other hand, the U.S. Preventive Services Task Force concludes that the evidence is insufficient to recommend for or against routine screening for thyroid disease in adults [141].

There is a need for large studies designed to answer the question whether thyroid abnormalities (and especially $\mathrm{SH}$ ) are associated with CVD and whether restoration of euthyroidism might influence morbidity and mortality.

\section{REFERENCES}

[1] Duntas LH. Thyroid disease and lipids. Thyroid 2002; 12: 287-93.

[2] Friis T, Pedersen LR. Serum lipids in hyper- and hypothyroidism before and after treatment. Clin Chim Acta 1987; 162: 155-63.

[3] Canaris GJ, Manowitz NR, Mayor G, Ridgway EC. The Colorado thyroid disease prevalence study. Arch Intern Med 2000; 160: 52634.

[4] Asvold BO, Vatten LJ, Nilsen TI, Bjoro T. The association between TSH within the reference range and serum lipid concentrations in a population-based study. The HUNT Study. Eur J Endocrinol 2007; 156: 181-6.

[5] Bakker O, Hudig F, Meijssen S, Wiersinga WM. Effects of triiodothyronine and amiodarone on the promoter of the human LDL receptor gene. Biochem Biophys Res Commun 1998; 249: 517-21.

[6] Shin DJ, Osborne TF. Thyroid hormone regulation and cholesterol metabolism are connected through Sterol Regulatory ElementBinding Protein-2 (SREBP-2). J Biol Chem 2003; 278: 34114-8.

[7] Faure P, Oziol L, Artur Y, Chomard P. Thyroid hormone (T3) and its acetic derivative (TA3) protect low-density lipoproteins from oxidation by different mechanisms. Biochimie 2004; 86: 411-8.

[8] Lagrost L. Regulation of cholesteryl ester transfer protein (CETP) activity: review of in vitro and in vivo studies. Biochim Biophys Acta 1994; 1215: 209-36.
[9] Kuusi T, Saarinen P, Nikkila EA. Evidence for the role of hepatic endothelial lipase in the metabolism of plasma high density lipoprotein2 in man. Atherosclerosis 1980; 36: 589-93.

[10] Santamarina-Fojo S, Gonzalez-Navarro H, Freeman L, Wagner E, Nong Z. Hepatic lipase, lipoprotein metabolism, and atherogenesis. Arterioscler Thromb Vasc Biol 2004; 24: 1750-4.

[11] Prieur X, Huby T, Coste H, Schaap FG, Chapman MJ, Rodriguez JC. Thyroid hormone regulates the hypotriglyceridemic gene APOA5. J Biol Chem 2005; 280: 27533-43.

[12] Rensen PC, van Dijk KW, Havekes LM. Apolipoprotein AV: low concentration, high impact. Arterioscler Thromb Vasc Biol 2005; 25: 2445-7.

[13] Iglesias P, Diez JJ. Influence of thyroid dysfunction on serum concentrations of adipocytokines. Cytokine 2007; 40: 61-70.

[14] Viguerie N, Millet L, Avizou S, Vidal H, Larrouy D, Langin D. Regulation of human adipocyte gene expression by thyroid hormone. J Clin Endocrinol Metab 2002; 87: 630-4.

[15] Hsieh CJ, Wang PW. Serum concentrations of adiponectin in patients with hyperthyroidism before and after control of thyroid function. Endocr J 2008; 55: 489-94.

[16] Crunkhorn S, Patti ME. Links between thyroid hormone action, oxidative metabolism, and diabetes risk? Thyroid 2008; 18: 227-37. Fernandez-Real JM, Lopez-Bermejo A, Castro A, Casamitjana R, Ricart W. Thyroid function is intrinsically linked to insulin sensitivity and endothelium-dependent vasodilation in healthy euthyroid subjects. J Clin Endocrinol Metab 2006; 91: 3337-43.

[18] Chubb SA, Davis WA, Davis TM. Interactions among thyroid function, insulin sensitivity, and serum lipid concentrations: the Fremantle diabetes study. J Clin Endocrinol Metab 2005; 90: 5317 20.

[19] Roos A, Bakker SJ, Links TP, Gans RO, Wolffenbuttel BH. Thyroid function is associated with components of the metabolic syndrome in euthyroid subjects. J Clin Endocrinol Metab 2007; 92: 491-6.

[20] Venditti P, Di Meo S. Thyroid hormone-induced oxidative stress. Cell Mol Life Sci 2006; 63: 414-34.

[21] Auer J, Berent R, Weber T, Lassnig E, Eber B. Thyroid function is associated with presence and severity of coronary atherosclerosis. Clin Cardiol 2003; 26: 569-73.

[22] De Pergola G, Ciampolillo A, Paolotti S, Trerotoli P, Giorgino R. Free triiodothyronine and thyroid stimulating hormone are directly associated with waist circumference, independently of insulin resistance, metabolic parameters and blood pressure in overweight and obese women. Clin Endocrinol (Oxf) 2007; 67: 265-9.

[23] Knudsen N, Laurberg P, Rasmussen LB, et al. Small differences in thyroid function may be important for body mass index and the occurrence of obesity in the population. J Clin Endocrinol Metab 2005; 90: 4019-24.

[24] Nyrnes A, Jorde R, Sundsfjord J. Serum TSH is positively associated with BMI. Int J Obes (Lond) 2006; 30: 100-5.

[25] Tsimihodimos V, Bairaktari E, Tzallas C, Miltiadus G, Liberopoulos E, Elisaf M. The incidence of thyroid function abnormalities in patients attending an outpatient lipid clinic. Thyroid 1999; 9: 365-8.

[26] Stone NJ. Secondary causes of hyperlipidemia. Med Clin North Am 1994; 78: 117-41.

[27] Pearce EN, Wilson PW, Yang Q, Vasan RS, Braverman LE. Thyroid function and lipid subparticle sizes in patients with shortterm hypothyroidism and a population-based cohort. J Clin Endocrinol Metab 2008; 93: 888-94.

[28] Abbas JM, Chakraborty J, Akanji AO, Doi SA. Hypothyroidism results in small dense LDL independent of IRS traits and hypertriglyceridemia. Endocr J 2008; 55: 381-9.

[29] Al-Tonsi AA, Abdel-Gayoum AA, Saad M. The secondary dyslipidemia and deranged serum phosphate concentration in thyroid disorders. Exp Mol Pathol 2004; 76: 182-7.

[30] Teixeira Pde F, Reuters VS, Ferreira MM, et al. Lipid profile in different degrees of hypothyroidism and effects of levothyroxine replacement in mild thyroid failure. Transl Res 2008; 151: 224-31.

[31] Lee WY, Suh JY, Rhee EJ, Park JS, Sung KC, Kim SW. Plasma CRP, apolipoprotein A-1, apolipoprotein B and $\mathrm{Lp}$ (a) levels according to thyroid function status. Arch Med Res 2004; 35: 5405.

[32] Walton KW, Scott PJ, Dykes PW, Davies JW. The significance of alterations in serum lipids in thyroid dysfunction. II. Alterations of 
the metabolism and turnover of 131-I-low-density lipoproteins in hypothyroidism and thyrotoxicosis. Clin Sci 1965; 29: 217-38.

[33] Thompson GR, Soutar AK, Spengel FA, Jadhav A, Gavigan SJ, Myant NB. Defects of receptor-mediated low density lipoprotein catabolism in homozygous familial hypercholesterolemia and hypothyroidism in vivo. Proc Natl Acad Sci USA 1981; 78: 25915 .

[34] Abrams JJ, Grundy SM. Cholesterol metabolism in hypothyroidism and hyperthyroidism in man. J Lipid Res 1981; 22: 323-38.

[35] Nikkila EA, Kekki M. Plasma triglyceride metabolism in thyroid disease. J Clin Invest 1972; 51: 2103-14.

[36] Lam KS, Chan MK, Yeung RT. High-density lipoprotein cholesterol, hepatic lipase and lipoprotein lipase activities in thyroid dysfunction--effects of treatment. Q J Med 1986; 59: 51321.

[37] Dullaart RP, Hoogenberg K, Groener JE, Dikkeschei LD, Erkelens DW, Doorenbos H. The activity of cholesteryl ester transfer protein is decreased in hypothyroidism: a possible contribution to alterations in high-density lipoproteins. Eur J Clin Invest 1990; 20: 581-7.

[38] de Bruin TW, van Barlingen H, van Linde-Sibenius Trip M, van Vuurst de Vries AR, Akveld MJ, Erkelens DW. Lipoprotein(a) and apolipoprotein B plasma concentrations in hypothyroid, euthyroid, and hyperthyroid subjects. J Clin Endocrinol Metab 1993; 76: 1216.

[39] Tzotzas T, Krassas GE, Konstantinidis T, Bougoulia M. Changes in lipoprotein(a) levels in overt and subclinical hypothyroidism before and during treatment. Thyroid 2000; 10: 803-8.

[40] Klausen IC, Nielsen FE, Hegedus L, Gerdes LU, Charles P, Faergeman O. Treatment of hypothyroidism reduces low-density lipoproteins but not lipoprotein(a). Metabolism 1992; 41: 911-4.

[41] Third Report of the National Cholesterol Education Program (NCEP) Expert Panel on Detection, Evaluation, and Treatment of High Blood Cholesterol in Adults (Adult Treatment Panel III) final report. Circulation 2002; 106: 3143-421.

[42] Kim CS, Kang JG, Lee SJ, et al. Relationship of low-density lipoprotein (LDL) particle size to thyroid function status in Koreans. Clin Endocrinol (Oxf) 2009; 71: 130-6.

[43] Roscini AR, Lupattelli G, Siepi D, Pagliaricci S, Pirro M, Mannarino E. Low-density lipoprotein size in primary hypothyroidism. Effects of hormone replacement therapy. Ann Nutr Metab 1999; 43: 374-9.

[44] Tunbridge WM, Evered DC, Hall R, et al. Lipid profiles and cardiovascular disease in the Whickham area with particular reference to thyroid failure. Clin Endocrinol (Oxf) 1977; 7: 495508.

[45] Pucci E, Chiovato L, Pinchera A. Thyroid and lipid metabolism. Int J Obes Relat Metab Disord 2000; 24(Suppl 2): S109-12.

[46] Costantini F, Pierdomenico SD, De Cesare D, et al. Effect of thyroid function on LDL oxidation. Arterioscler Thromb Vasc Biol 1998; 18: 732-7.

[47] Morris MS, Bostom AG, Jacques PF, Selhub J, Rosenberg IH. Hyperhomocysteinemia and hypercholesterolemia associated with hypothyroidism in the third US National Health and Nutrition Examination Survey. Atherosclerosis 2001; 155: 195-200.

[48] Bicikova M, Tallova J, Hill M, Vanuga A, Putz Z, Tomandl J. Effect of treatment of hypothyroidism on the plasma concentrations of neuroactive steroids and homocysteine. Clin Chem Lab Med 2001; 39: 753-7.

[49] Christ-Crain M, Meier C, Guglielmetti M, et al. Elevated Creactive protein and homocysteine values: cardiovascular risk factors in hypothyroidism? A cross-sectional and a double-blind, placebo-controlled trial. Atherosclerosis 2003; 166: 379-86.

[50] Mayer O, Jr, Simon J, Filipovsky J, Plaskova M, Pikner R. Hypothyroidism in coronary heart disease and its relation to selected risk factors. Vasc Health Risk Manag 2006; 2: 499-506.

[51] Kreisman SH, Hennessey JV. Consistent reversible elevations of serum creatinine levels in severe hypothyroidism. Arch Intern Med 1999; 159: 79-82.

[52] Cimino JA, Jhangiani S, Schwartz E, Cooperman JM. Riboflavin metabolism in the hypothyroid human adult. Proc Soc Exp Biol Med 1987; 184: 151-3.

[53] Fommei E, Iervasi G. The role of thyroid hormone in blood pressure homeostasis: evidence from short-term hypothyroidism in humans. J Clin Endocrinol Metab 2002; 87: 1996-2000.
[54] Dernellis J, Panaretou M. Effects of thyroid replacement therapy on arterial blood pressure in patients with hypertension and hypothyroidism. Am Heart J 2002; 143: 718-24.

[55] Klein I. Thyroid hormone and the cardiovascular system. Am J Med 1990; 88: 631-7.

[56] Hamano K, Inoue M. Increased risk for atherosclerosis estimated by pulse wave velocity in hypothyroidism and its reversal with appropriate thyroxine treatment. Endocr J 2005; 52: 95-101.

[57] Dagre AG, Lekakis JP, Papaioannou TG, et al. Arterial stiffness is increased in subjects with hypothyroidism. Int J Cardiol 2005; 103: $1-6$.

[58] Lekakis J, Papamichael C, Alevizaki M, et al. Flow-mediated, endothelium-dependent vasodilation is impaired in subjects with hypothyroidism, borderline hypothyroidism, and high-normal serum thyrotropin (TSH) values. Thyroid 1997; 7: 411-4.

[59] Feig DI, Kang DH, Johnson RJ. Uric acid and cardiovascular risk. N Engl J Med 2008; 359: 1811-21.

[60] Caudarella R, Vescini F, Buffa A, Francucci CM. Hyperphosphatemia: effects on bone metabolism and cardiovascular risk. J Endocrinol Invest 2007; 30: 29-34.

[61] Nagasaki T, Inaba M, Henmi Y, et al. Decrease in carotid intimamedia thickness in hypothyroid patients after normalization of thyroid function. Clin Endocrinol (Oxf) 2003; 59: 607-12.

[62] Raterman HG, van Eijk IC, Voskuyl AE, et al. The metabolic syndrome is amplified in hypothyroid rheumatoid arthritis patients: a cross sectional study. Ann Rheum Dis 2010; 69: 39-42.

[63] Jung CH, Sung KC, Shin HS, et al. Thyroid dysfunction and their relation to cardiovascular risk factors such as lipid profile, hsCRP, and waist hip ratio in Korea. Korean J Intern Med 2003; 18: 146-53.

[64] Maratou E, Hadjidakis DJ, Kollias A, et al. Studies of insulin resistance in patients with clinical and subclinical hypothyroidism. Eur J Endocrinol 2009; 160: 785-90.

[65] Shepherd PR, Kahn BB. Glucose transporters and insulin action-implications for insulin resistance and diabetes mellitus. N Engl J Med 1999; 341: 248-57.

[66] Wiseman SA, Powell JT, Humphries SE, Press M. The magnitude of the hypercholesterolemia of hypothyroidism is associated with variation in the low density lipoprotein receptor gene. J Clin Endocrinol Metab 1993; 77: 108-12.

[67] Elder J, McLelland A, O'Reilly DS, Packard CJ, Series JJ, Shepherd J. The relationship between serum cholesterol and serum thyrotropin, thyroxine and tri-iodothyronine concentrations in suspected hypothyroidism. Ann Clin Biochem 1990; 27 ( Pt 2): 110-3.

[68] Verdugo C, Perrot L, Ponsin G, Valentin C, Berthezene F. Timecourse of alterations of high density lipoproteins (HDL) during thyroxine administration to hypothyroid women. Eur J Clin Invest 1987; 17: 313-6.

[69] Beyer IW, Karmali R, Demeester-Mirkine N, Cogan E, Fuss MJ. Serum creatine kinase levels in overt and subclinical hypothyroidism. Thyroid 1998; 8: 1029-31.

[70] Tokinaga K, Oeda T, Suzuki Y, Matsushima Y. HMG-CoA reductase inhibitors (statins) might cause high elevations of creatine phosphokinase $(\mathrm{CK})$ in patients with unnoticed hypothyroidism. Endocr J 2006; 53: 401-5.

[71] Hollowell JG, Staehling NW, Flanders WD, et al. Serum TSH, T(4), and thyroid antibodies in the United States population (1988 to 1994): National Health and Nutrition Examination Survey (NHANES III). J Clin Endocrinol Metab 2002; 87: 489-99.

[72] Danese MD, Ladenson PW, Meinert CL, Powe NR. Clinical review 115: effect of thyroxine therapy on serum lipoproteins in patients with mild thyroid failure: a quantitative review of the literature. $\mathrm{J}$ Clin Endocrinol Metab 2000; 85: 2993-3001.

[73] Samuels MH. Subclinical thyroid disease in the elderly. Thyroid 1998; 8: 803-13.

[74] Luboshitzky R, Aviv A, Herer P, Lavie L. Risk factors for cardiovascular disease in women with subclinical hypothyroidism. Thyroid 2002; 12: 421-5.

[75] Vanderpump MP, Tunbridge WM, French JM, et al. The incidence of thyroid disorders in the community: a twenty-year follow-up of the Whickham Survey. Clin Endocrinol (Oxf) 1995; 43: 55-68.

[76] Tanis BC, Westendorp GJ, Smelt HM. Effect of thyroid substitution on hypercholesterolaemia in patients with subclinical hypothyroidism: a reanalysis of intervention studies. Clin Endocrinol (Oxf) 1996; 44: 643-9. 
[77] Erem C. Blood coagulation, fibrinolytic activity and lipid profile in subclinical thyroid disease: subclinical hyperthyroidism increases plasma factor X activity. Clin Endocrinol (Oxf) 2006; 64: 323-9.

[78] Duman D, Demirtunc R, Sahin S, Esertas K. The effects of simvastatin and levothyroxine on intima-media thickness of the carotid artery in female normolipemic patients with subclinical hypothyroidism: a prospective, randomized-controlled study. J Cardiovasc Med (Hagerstown) 2007; 8: 1007-11.

[79] Monzani F, Caraccio N, Kozakowa M, et al. Effect of levothyroxine replacement on lipid profile and intima-media thickness in subclinical hypothyroidism: a double-blind, placebocontrolled study. J Clin Endocrinol Metab 2004; 89: 2099-106.

[80] Walsh JP, Bremner AP, Bulsara MK, et al. Thyroid dysfunction and serum lipids: a community-based study. Clin Endocrinol (Oxf) 2005; 63: 670-5.

[81] Milionis HJ, Tambaki AP, Kanioglou CN, Elisaf MS, Tselepis AD, Tsatsoulis A. Thyroid substitution therapy induces high-density lipoprotein-associated platelet-activating factor-acetylhydrolase in patients with subclinical hypothyroidism: a potential antiatherogenic effect. Thyroid 2005; 15: 455-60.

[82] Toruner F, Altinova AE, Karakoc A, et al. Risk factors for cardiovascular disease in patients with subclinical hypothyroidism. Adv Ther 2008; 25: 430-7.

[83] Erdem TY, Ercan M, Ugurlu S, Balci H, Acbay O, Gundogdu S. Plasma viscosity, an early cardiovascular risk factor in women with subclinical hypothyroidism. Clin Hemorheol Microcirc 2008; 38: 219-25.

[84] Michalopoulou G, Alevizaki M, Piperingos G, et al. High serum cholesterol levels in persons with 'high-normal' TSH levels: should one extend the definition of subclinical hypothyroidism? Eur $\mathbf{J}$ Endocrinol 1998; 138: 141-5.

[85] Efstathiadou Z, Bitsis S, Milionis HJ, et al. Lipid profile in subclinical hypothyroidism: is L-thyroxine substitution beneficial? Eur J Endocrinol 2001; 145: 705-10.

[86] Iqbal A, Jorde R, Figenschau Y. Serum lipid levels in relation to serum thyroid-stimulating hormone and the effect of thyroxine treatment on serum lipid levels in subjects with subclinical hypothyroidism: the Tromso Study. J Intern Med 2006; 260: 53-61.

[87] Kung AW, Pang RW, Janus ED. Elevated serum lipoprotein(a) in subclinical hypothyroidism. Clin Endocrinol (Oxf) 1995; 43: 4459.

[88] Caraccio N, Ferrannini E, Monzani F. Lipoprotein profile in subclinical hypothyroidism: response to levothyroxine replacement, a randomized placebo-controlled study. J Clin Endocrinol Metab 2002; 87: 1533-8.

[89] Milionis HJ, Efstathiadou Z, Tselepis AD, et al. Lipoprotein (a) levels and apolipoprotein (a) isoform size in patients with subclinical hypothyroidism: effect of treatment with levothyroxine. Thyroid 2003; 13: 365-9.

[90] Lotz H, Salabe GB. Lipoprotein(a) increase associated with thyroid autoimmunity. Eur J Endocrinol 1997; 136: 87-91.

[91] Bairaktari ET, Tselepis AD, Millionis HJ, Elisaf MS. Lipoprotein (a) levels, apolipoprotein (a) phenotypes and thyroid autoimmunity. Eur J Endocrinol 1999; 140: 474-6.

[92] Bairaktari ET, Milionis HJ, Katopodis K, et al. Lipoprotein (a), Apolipoprotein (a) phenotypes, and thyroid autoimmunity in uremic patients. Endocrinologist 2000; 10: 383-88.

[93] Brenta G, Berg G, Arias P, et al. Lipoprotein alterations, hepatic lipase activity, and insulin sensitivity in subclinical hypothyroidism: response to L-T(4) treatment. Thyroid 2007; 17: 453-60.

[94] Hueston WJ, Pearson WS. Subclinical hypothyroidism and the risk of hypercholesterolemia. Ann Fam Med 2004; 2: 351-5.

[95] Yildirimkaya M, Ozata M, Yilmaz K, Kilinc C, Gundogan MA, Kutluay T. Lipoprotein(a) concentration in subclinical hypothyroidism before and after levo-thyroxine therapy. Endocr J 1996; 43: 731-6.

[96] Lippi G, Targher G, Montagnana M, Salvagno GL, Guidi GC. Relationship between lipoprotein(a) and thyroid function status in the general population. Arch Med Res 2007; 38: 905-6.

[97] Bakker SJ, ter Maaten JC, Popp-Snijders C, Slaets JP, Heine RJ, Gans RO. The relationship between thyrotropin and low density lipoprotein cholesterol is modified by insulin sensitivity in healthy euthyroid subjects. J Clin Endocrinol Metab 2001; 86: 1206-11.

[98] Kahaly GJ. Cardiovascular and atherogenic aspects of subclinical hypothyroidism. Thyroid 2000; 10: 665-79.
[99] Taddei S, Caraccio N, Virdis A, et al. Impaired endotheliumdependent vasodilatation in subclinical hypothyroidism: beneficial effect of levothyroxine therapy. J Clin Endocrinol Metab 2003; 88: 3731-7.

[100] Cabral MD, Teixeira PF, Silva NA, et al. Normal flow-mediated vasodilatation of the brachial artery and carotid artery intima-media thickness in subclinical hypothyroidism. Braz J Med Biol Res 2009; 42: 426-32.

[101] Yun KH, Jeong MH, Oh SK, et al. Relationship of thyroid stimulating hormone with coronary atherosclerosis in angina patients. Int J Cardiol 2007; 122: 56-60.

[102] Chiche F, Jublanc C, Coudert M, Carreau V, Kahn JF, Bruckert E. Hypothyroidism is not associated with increased carotid atherosclerosis when cardiovascular risk factors are accounted for in hyperlipidemic patients. Atherosclerosis 2009; 203: 269-76.

[103] Dessein PH, Joffe BI, Stanwix AE. Subclinical hypothyroidism is associated with insulin resistance in rheumatoid arthritis. Thyroid 2004; 14: 443-6.

[104] Packard CJ, O'Reilly DS, Caslake MJ, et al. Lipoprotein-associated phospholipase A2 as an independent predictor of coronary heart disease. West of Scotland Coronary Prevention Study Group. N Engl J Med 2000; 343: 1148-55.

[105] Mertens A, Holvoet P. Oxidized LDL and HDL: antagonists in atherothrombosis. FASEB J 2001; 15: 2073-84.

[106] Jublanc C, Bruckert E, Giral P, et al. Relationship of circulating Creactive protein levels to thyroid status and cardiovascular risk in hyperlipidemic euthyroid subjects: low free thyroxine is associated with elevated hsCRP. Atherosclerosis 2004; 172: 7-11.

[107] Asvold BO, Bjoro T, Nilsen TI, Vatten LJ. Association between blood pressure and serum thyroid-stimulating hormone concentration within the reference range: a population-based study. J Clin Endocrinol Metab 2007; 92: 841-5.

[108] Duan Y, Peng W, Wang X, et al. Community-based study of the association of subclinical thyroid dysfunction with blood pressure. Endocrine 2009; 35: 136-142.

[109] Muller B, Zulewski H, Huber P, Ratcliffe JG, Staub JJ. Impaired action of thyroid hormone associated with smoking in women with hypothyroidism. N Engl J Med 1995; 333: 964-9.

[110] Rodondi N, Aujesky D, Vittinghoff E, Cornuz J, Bauer DC. Subclinical hypothyroidism and the risk of coronary heart disease: a meta-analysis. Am J Med 2006; 119: 541-51.

[111] Rodondi N, Newman AB, Vittinghoff E, et al. Subclinical hypothyroidism and the risk of heart failure, other cardiovascular events, and death. Arch Intern Med 2005; 165: 2460-6.

[112] Haentjens P, Van Meerhaeghe A, Poppe K, Velkeniers B. Subclinical thyroid dysfunction and mortality: an estimate of relative and absolute excess all-cause mortality based on time-toevent data from cohort studies. Eur J Endocrinol 2008; 159: 32941.

[113] Imaizumi M, Akahoshi M, Ichimaru S, et al. Risk for ischemic heart disease and all-cause mortality in subclinical hypothyroidism. J Clin Endocrinol Metab 2004; 89: 3365-70.

[114] Hak AE, Pols HA, Visser TJ, Drexhage HA, Hofman A, Witteman JC. Subclinical hypothyroidism is an independent risk factor for atherosclerosis and myocardial infarction in elderly women: the Rotterdam Study. Ann Intern Med 2000; 132: 270-8.

[115] Cappola AR, Fried LP, Arnold AM, et al. Thyroid status, cardiovascular risk, and mortality in older adults. JAMA 2006; 295: 1033-41.

[116] Gussekloo J, van Exel E, de Craen AJ, Meinders AE, Frolich M, Westendorp RG. Thyroid status, disability and cognitive function, and survival in old age. JAMA 2004; 292: 2591-9.

[117] Mikhail GS, Alshammari SM, Alenezi MY, Mansour M, Khalil NA. Increased atherogenic low-density lipoprotein cholesterol in untreated subclinical hypothyroidism. Endocr Pract 2008; 14: 5705.

[118] Ganotakis ES, Mandalaki K, Tampakaki M, et al. Subclinical hypothyroidism and lipid abnormalities in older women attending a vascular disease prevention clinic: effect of thyroid replacement therapy. Angiology 2003; 54: 569-76.

[119] Meier C, Staub JJ, Roth CB, et al. TSH-controlled L-thyroxine therapy reduces cholesterol levels and clinical symptoms in subclinical hypothyroidism: a double blind, placebo-controlled trial (Basel Thyroid Study). J Clin Endocrinol Metab 2001; 86: 4860-6.

[120] Razvi S, Ingoe L, Keeka G, Oates C, McMillan C, Weaver JU. The beneficial effect of L-thyroxine on cardiovascular risk factors, 
endothelial function, and quality of life in subclinical hypothyroidism: randomized, crossover trial. J Clin Endocrinol Metab 2007; 92: 1715-23.

[121] Duman D, Sahin S, Esertas K, Demirtunc R. Simvastatin improves endothelial function in patents with subclinical hypothyroidism. Heart Vessels 2007; 22: 88-93.

[122] Kong WM, Sheikh MH, Lumb PJ, et al. A 6-month randomized trial of thyroxine treatment in women with mild subclinical hypothyroidism. Am J Med 2002; 112: 348-54.

[123] Villar HC, Saconato H, Valente O, Atallah AN. Thyroid hormone replacement for subclinical hypothyroidism. Cochrane Database Syst Rev 2007: CD003419.

[124] Fatourechi V. Subclinical hypothyroidism: an update for primary care physicians. Mayo Clin Proc 2009; 84: 65-71.

[125] Biondi B, Cooper DS. The clinical significance of subclinical thyroid dysfunction. Endocr Rev 2008; 29: 76-131.

[126] Feldt-Rasmussen U. Is the treatment of subclinical hypothyroidism beneficial? Nat Clin Pract Endocrinol Metab 2009; 5: 86-7.

[127] Cooper DS. Subclinical thyroid disease: a clinician's perspective. Ann Intern Med 1998; 129: 135-8.

[128] Helfand M, Redfern CC. Clinical guideline, part 2. Screening for thyroid disease: an update. American College of Physicians. Ann Intern Med 1998; 129: 144-58.

[129] Ayala AR, Danese MD, Ladenson PW. When to treat mild hypothyroidism. Endocrinol Metab Clin North Am 2000; 29: 399-415.

[130] Kung AW, Pang RW, Lauder I, Lam KS, Janus ED. Changes in serum lipoprotein(a) and lipids during treatment of hyperthyroidism. Clin Chem 1995; 41: 226-31.

[131] Aviram M, Luboshitzky R, Brook JG. Lipid and lipoprotein pattern in thyroid dysfunction and the effect of therapy. Clin Biochem 1982; 15: 62-6.
[132] Cooper DS. Approach to the patient with subclinical hyperthyroidism. J Clin Endocrinol Metab 2007; 92: 3-9.

[133] Bergeron GA, Goldsmith R, Schiller NB. Myocardial infarction, severe reversible ischemia, and shock following excess thyroid administration in a woman with normal coronary arteries. Arch Intern Med 1988; 148: 1450-3.

[134] Gowda RM, Khan IA, Soodini G, Vasavada BC, Sacchi TJ. Acute myocardial infarction with normal coronary arteries associated with iatrogenic hyperthyroidism. Int J Cardiol 2003; 90: 327-9.

[135] Patane S, Marte F. Atrial fibrillation and acute myocardial infarction without significant coronary stenoses associated with subclinical hyperthyroidism and erythrocytosis. Int J Cardiol 2009 (Article in press).

[136] Patane S, Marte F, Curro A, Cimino C. Recurrent acute pulmonary embolism and paroxysmal atrial fibrillation associated with subclinical hyperthyroidism. Int J Cardiol 2010; 142: e25-6.

[137] Liberopoulos E, Miltiadous G, Elisaf M. Impressive lipid changes following hypolipidaemic drug administration can unveil subclinical hyperthyroidism. Diabetes Obes Metab 2001; 3: 97-8.

[138] Liberopoulos EN, Elisaf MS. Dyslipidemia in patients with thyroid disorders. Hormones (Athens) 2002; 1: 218-23.

[139] Danese MD, Powe NR, Sawin CT, Ladenson PW. Screening for mild thyroid failure at the periodic health examination: a decision and cost-effectiveness analysis. JAMA 1996; 276: 285-92.

[140] Ladenson PW, Singer PA, Ain KB, et al. American Thyroid Association guidelines for detection of thyroid dysfunction. Arch Intern Med 2000; 160: 1573-5.

[141] U.S. Preventive Services Task Force. Screening for thyroid disease: recommendation statement. Ann Intern Med 2004; 140: 125-7.

Received: December 08, 2010

Revised: January 05, 2011

Accepted: January 06, 2011

(C) Rizos et al.; Licensee Bentham Open.

This is an open access article licensed under the terms of the Creative Commons Attribution Non-Commercial License (http://creativecommons.org/licenses/ by-nc/3.0/) which permits unrestricted, non-commercial use, distribution and reproduction in any medium, provided the work is properly cited. 